\title{
Mercury bioremoval by Yarrowia strains isolated from sediments of mercury-polluted estuarine water
}

\author{
Ganiyu Oladunjoye Oyetibo • Shakirat Titilayo Ishola • \\ Wakako Ikeda-Ohtsubo • Keisuke Miyauchi • \\ Matthew Olusoji Ilori • Ginro Endo
}

Received: 28 July 2014 /Revised: 27 November 2014 / Accepted: 29 November 2014 / Published online: 18 December 2014

(C) The Author(s) 2014. This article is published with open access at Springerlink.com

\begin{abstract}
Difference in mercuric ion removal by resting and growing cells of two mercury-resistant yeast strains, identified as Yarrowia spp. (strains Idd1 and Idd2), were studied. Resting cells of strain Idd 2 exhibited high maximum $\mathrm{Hg}^{2+}$ removal capacity (59 $\mathrm{mg}$ mercury per $\mathrm{g}$ dry cell weight $\left.\left[\mathrm{gdw}^{-1}\right]\right)$ by adsorption than those of resting cells of strain Idd1 $\left(32 \mathrm{mg} \mathrm{gdw}^{-1}\right)$. The resting cells of strain Idd2 exhibited a higher $\mathrm{Hg}^{2+}$ desorption capacity using $\mathrm{CaCl}_{2}(68 \%)$ and EDTA (48 \%) than strain Idd1, depicting weaker binding of $\mathrm{Hg}^{2+}$ onto strain Idd 2 unlike strain Idd1. The actively growing yeast cells showed opposite $\mathrm{Hg}$ removal characteristics to those of the resting cells. Strain Idd1 adsorbed less $\mathrm{Hg}^{2+}$ from
\end{abstract}

Electronic supplementary material The online version of this article (doi:10.1007/s00253-014-6279-1) contains supplementary material, which is available to authorized users.

G. O. Oyetibo $\cdot$ W. Ikeda-Ohtsubo $\cdot$ K. Miyauchi $\cdot$ G. Endo $(\bowtie)$

Department of Civil and Environmental Engineering, Faculty of Engineering, Tohoku Gakuin University, 1-13-1 Chuo, Tagajo,

Miyagi 985-8537, Japan

e-mail: gendo@mail.tohoku-gakuin.ac.jp

G. O. Oyetibo

e-mail: goyetibo@unilag.edu.ng

G. O. Oyetibo

e-mail: goyetibo@mail.tohoku-gakuin.ac.jp

W. Ikeda-Ohtsubo

e-mail:wohtsubo@mail.tohoku-gakuin.ac.jp

K. Miyauchi

e-mail:kmiya@mail.tohoku-gakuin.ac.jp

G. O. Oyetibo $\cdot$ S. T. Ishola $\cdot$ M. O. Ilori

Department of Microbiology, Faculty of Science, University of

Lagos, Akoka, Yaba, Lagos, Nigeria

S. T. Ishola

e-mail: ishola_titilayo@yahoo.com

M. O. Ilori

e-mail: milori@unilag.edu.ng culture medium supplemented with $\mathrm{Hg}^{2+}$ than strain Idd2. However, the growing strain Idd1 reduced and vaporized $27 \%$ of supplemented $\mathrm{Hg}^{2+}$ as metallic mercury $\left(\mathrm{Hg}^{0}\right)$, while the growing strains Idd 2 vaporized $15 \%$ of the supplemented $\mathrm{Hg}^{2+}$. These two yeast strains are potential biotechnological tools for the eventual bioremediation of polluted aquatic systems.

Keywords Mercury-resistant yeast $\cdot$ Resting and growing cells $\cdot$ Mercury bioremoval $\cdot$ Biosorption $\cdot$ Biovolatilization

\section{Introduction}

Mercury is a major pollutant and the most widely distributed toxic metal in the environment (Tchounwon et al. 2003). Natural sources are the major means through which $\mathrm{Hg}$ is introduced into the environment (Tomiyasu et al. 2006; 2008). However, anthropogenic activities remain an unparalleled channel through which various species of $\mathrm{Hg}$ polluted the biosphere (AMAP/UNEP 2013; Nimick et al. 2013; Tomiyasu et al. 2006; 2008). Hg pollution has gained global awareness because it is ubiquitous in most environments (AMAP/UNEP 2013) and because its toxicity causes several effects on human health (Guzzi and La Porta 2008). Hg often transforms into highly neurotoxic methyl-mercury (ATSDR 2008) and biomagnifies upward through the food chain in aquatic ecosystems (Kim et al. 2004).

$\mathrm{Hg}$ is toxic, but some microorganisms that exhibit resistance are found in systems contaminated with Hg. Various genera of bacteria and fungi have been reported to tolerate $\mathrm{Hg}$ (von Canstein et al. 1999 and von Canstein et al. 2002; Huang et al. 1999; Yavuz et al. 2006; Francois et al. 2012). The physicochemical and biological processes leading to the removal and/or sequestration of $\mathrm{Hg}$ are bio-remedial strategies proposed to alleviate systems polluted with $\mathrm{Hg}$ (Francois et al. 
2012; Hussein et al. 2004; Velasquez and Dussan 2009). Pitfalls of non-biological approaches to $\mathrm{Hg}$ removal (Hussein et al. 2004) make a microbial-based technology for the detoxification of $\mathrm{Hg}$ in polluted systems a better remediation option. The applicability of Hg-resistant microorganisms for the determination of the fate of $\mathrm{Hg}$ is of great importance to environmental and public health sciences. Several reports have articulated the use of microorganisms to efficiently remove $\mathrm{Hg}$ from contaminated matrixes via biological reduction (von Canstein et al. 1999 and von Canstein et al. 2002), biosorption (Francois et al. 2012; Velasquez and Dussan 2009), bioaccumulation (Velasquez and Dussan 2009), and biosequestration (Francois et al. 2012). Bacterial strains that harbor merA genes are known to reduce $\mathrm{Hg}^{2+}$ to volatile $\mathrm{Hg}^{0}$ (Huang et al. 1999; von Canstein et al. 1999; 2002). Thereby, removing $\mathrm{Hg}$ from local environment is achieved by using mercury-resistant microorganisms.

Although yeast cells are generally known to be mediocre in terms of metal biosorption (Voleski 1994), Yarrowia species have been reported to exhibit resistance to toxic concentrations of a number of heavy metals (Bankar et al. 2009; Strouhal et al. 2003). Despite many investigations on $\mathrm{Hg}$ resistance and detoxification by microorganisms, little is known about Hg resistance of Yarrowia species. Based on the available information, neither $\mathrm{Hg}$ volatilization nor its biosorption through resting cells has been linked to Yarrowia species. The present study sought to find appropriate microbial $\mathrm{Hg}$ removal agents using resting and growing $\mathrm{Hg}$ resistant Yarrowia yeast cells.

\section{Materials and methods}

Sampling and chemical reagents

Lagos Lagoon in Nigeria is an estuary water body more than $50 \mathrm{~km}$ in length and 3-13 km in width with a surface area of approximately $6400 \mathrm{~km}^{2}$. The densely populated city of Lagos spreads along the shore of more than $60 \%$ of the lagoon, which results in the exposure of the water to multifarious contaminants. The highly polluted water empties into the Atlantic Ocean. Composite samples of water and sediment from Lagos Lagoon $\left(06^{\circ} 27^{\prime} 99.7^{\prime \prime} \mathrm{N}, 003^{\circ} 22^{\prime} 85.1^{\prime \prime} \mathrm{E}\right)$ were collected and analyzed to determine their $\mathrm{Hg}$ content (see "Analyses of total mercury" below). $\mathrm{HgCl}_{2}$ used in this research was purchased from SigmaAldrich Corp. (St. Louis, MO, USA). Stock solutions $\left(100 \mathrm{gl}^{-1}\right)$ of $\mathrm{HgCl}_{2}$ were prepared and sterilized at $121^{\circ} \mathrm{C}$. All of the other chemicals used were of analytical reagent grade.

Isolation, culture conditions, and deposition of isolates

The sediment sample ( $10 \mathrm{~g})$ was enriched in a sterile starchcasein broth $(90 \mathrm{ml})$ supplemented with $2 \mathrm{mg} \mathrm{l}^{-1} \mathrm{Hg}^{2+}$. The starch casein broth contained $10 \mathrm{~g} \mathrm{l}^{-1}$ soluble starch, $2 \mathrm{~g} \mathrm{l}^{-1}$ $\mathrm{K}_{2} \mathrm{HPO}_{4}, 2 \mathrm{~g} \mathrm{l}^{-1} \mathrm{KNO}_{3}, 2 \mathrm{~g} \mathrm{l}^{-1} \mathrm{NaCl}, 0.3 \mathrm{~g} \mathrm{l}^{-1}$ casein, $0.05 \mathrm{~g} \mathrm{l}^{-1} \mathrm{MgSO}_{4} \cdot 7 \mathrm{H}_{2} \mathrm{O}, 0.02 \mathrm{~g} \mathrm{l}^{-1} \mathrm{CaCO}_{3}$, and $0.01 \mathrm{~g} \mathrm{l}^{-1}$ $\mathrm{FeSO}_{4} \cdot 7 \mathrm{H}_{2} \mathrm{O}$, pH 5.5 (approx.). After a 10-day incubation $\left(30^{\circ} \mathrm{C}, 150 \mathrm{rpm}\right), 100 \mu \mathrm{l}$ of the culture was spread on a dried surface of sterile Bacto YM broth (Difco, Detroit, MI, USA) solidified with $1.5 \%$ agar (Wako, Osaka, Japan). The YM broth contained $5 \mathrm{~g} \mathrm{l}^{-1}$ yeast extract, $3 \mathrm{~g} \mathrm{l}^{-1}$ malt extract, $5 \mathrm{~g} \mathrm{l}^{-1}$ peptone, and $10 \mathrm{~g} \mathrm{l}^{-1}$ dextrose. Three days postinoculation $\left(30^{\circ} \mathrm{C}\right)$, colonies were selected and stored in a water:glycerol $(1: 1)$ mixture at $-80{ }^{\circ} \mathrm{C}$. The isolated yeast strains have been deposited to Japan Collection of Microorganisms under accession no. JCM 30162 (strain Idd1) and JCM 30163 (strain Idd2).

\section{Determination of resistance pattern}

The isolated yeasts were screened to determine the minimum inhibitory concentration (MIC) of Hg, which is the concentration at which no growth of yeast was observed in the YM broth supplemented with $\mathrm{HgCl}_{2}\left(30^{\circ} \mathrm{C}, 150 \mathrm{rpm}, 48 \mathrm{~h}\right)$. The $\mathrm{Hg}$ concentrations in the YM broth used for the MIC determination were $2,4,8,16,32$, and $64 \mathrm{mg} \mathrm{l}^{-1}$. Two strains of yeast showing resistance to $32 \mathrm{mg} \mathrm{l}^{-1}$ were selected and subjected to further analysis.

Molecular characterization and identification of $\mathrm{Hg}$-resistant yeasts

DNA was isolated and purified using a Wizard DNA isolation kit (Promega Corp., Madison, WI, USA) according to the manufacturer's instructions. Using universal eukaryotic primer sets (Table S1), nearly full-length $18 \mathrm{~S}$ ribosomal RNA (rRNA) genes were amplified from the genomic DNA. Each PCR mixture contained $1 \mu \mathrm{l}$ of DNA template, $5 \mu \mathrm{l}$ of $10 \times$ Taq DNA polymerase buffer (TaKaRa, Ohtsu, Japan), $4 \mu \mathrm{l}$ of dNTP $\left(2.5 \mathrm{mmol} \mathrm{l}^{-1}\right.$ each; TaKaRa), $0.5 \mu \mathrm{l}$ of each primer $\left(50 \mu \mathrm{mol} 1^{-1}\right), 0.25 \mu \mathrm{l}$ of Ex-Taq DNA polymerase (TaKaRa), and $38.75 \mu \mathrm{l}$ of sterile Milli-Q water in a final volume of $50 \mu \mathrm{l}$. The PCR protocol consisted of an initial hot incubation ( $95^{\circ} \mathrm{C}, 5 \mathrm{~min}$ ), 30 amplification cycles (denaturation at $95^{\circ} \mathrm{C}$ for $45 \mathrm{~s}$, annealing at $55^{\circ} \mathrm{C}$ for $1 \mathrm{~min}$, and extension at $72{ }^{\circ} \mathrm{C}$ for $2.5 \mathrm{~min})$, and a final extension $\left(72{ }^{\circ} \mathrm{C}, 7 \mathrm{~min}\right)$ using a Gradient PCR Thermal Cycler Dice (TaKaRa). The 18S rRNA gene amplicons were sequenced using the Applied Biosystems 3130xl Genetic Analyzer and a BigDye Terminator v3.1 cycle sequencing kit (Applied Biosystems, Foster, CA, USA). The sequences were compared to those present in the database using BLAST $(\mathrm{N})$ and aligned using the Muscle 3.7 program. Regions with significant variations were automatically removed using the Gblocks software. The phylogeny of the aligned multiple sequences were analyzed with PhyML v3.0, and a phylogenetic tree was rendered using 
TreeDyn. The 18S rRNA gene sequences were deposited in GenBank under accession no. AB893170 (strain Idd1) and AB893171 (strain Idd2).

Determination of mercury removal through biosorption by resting yeast cells

The resuscitated yeast strains (approx. $10^{6}$ cells $\mathrm{ml}^{-1}$ as $\left.\mathrm{OD}_{600}=0.1\right)$ were starved overnight in Tris- $\mathrm{HCl}$ $\left(0.1 \mathrm{~mol} \mathrm{l}^{-1}\right)$ and re-suspended in sterile Milli-Q water (previously supplemented with $1.0 \mathrm{mg} \mathrm{l}^{-1} \mathrm{Hg}^{2+}$, final concentration) to prepare resting yeast cells. The yeast cell concentrations in the cell suspensions were determined as previously described (Puranik and Paknikar 1999).

To determine the $\mathrm{Hg}$ adsorption capacity of the yeast cells, a sufficient inoculum as prepared above $(25 \mathrm{mgdw}$ in $10 \mathrm{ml}$ of deionized water, approx.) was introduced into an Erlenmeyer flask containing $50 \mathrm{ml}$ of minimal medium (MM) supplemented with $6.0,12.0,24.0,48.0,96.0$, or $192.0 \mathrm{mg} \mathrm{l}^{-1} \mathrm{HgCl}_{2}$, and the culture was incubated $\left(50 \times g ; 30^{\circ} \mathrm{C}\right)$. The $\mathrm{MM}$ contained $10 \mathrm{~g} \mathrm{l}^{-1}$ glucose, $2.67 \mathrm{~g} \mathrm{l}^{-1} \mathrm{NH}_{4} \mathrm{Cl}$, and $5.35 \mathrm{~g} \mathrm{l}^{-1} \mathrm{Na}_{2} \mathrm{HPO}_{4}$ in $6 \mathrm{ml}$ of mineral salts solution $\left(0.1 \mathrm{~g}\right.$ of $\mathrm{CaCl}_{2} \cdot \mathrm{H}_{2} \mathrm{O}, 10 \mathrm{~g}$ of $\mathrm{MgSO}_{4} \cdot 7 \mathrm{H}_{2} \mathrm{O}, 0.07 \mathrm{~g}$ of $\mathrm{MnSO}_{4} \cdot 7 \mathrm{H}_{2} \mathrm{O}$, and $0.04 \mathrm{~g}$ of $\mathrm{FeSO}_{4}$. $7 \mathrm{H}_{2} \mathrm{O}$ in $1000 \mathrm{ml}$ of distilled water). At every $5 \mathrm{~min}$, the quantity of $\mathrm{Hg}$ adsorbed by the yeast cells was determined (as described below) after centrifugation (9000×g, $20 \mathrm{~min}$ ). The Hg adsorbed was calculated as $Q=\frac{V\left(C_{O}-C_{e}\right)}{m}$, where $\mathrm{Q}$ is the specific $\mathrm{Hg}$ uptake ( $\mathrm{mg} \mathrm{gdw}^{-1}$ ), $\mathrm{V}$ is the volume of the $\mathrm{Hg}$ solution ( $\mathrm{ml}), C_{O}$ is the initial $\mathrm{Hg}$ concentration in the solution $\left(\mathrm{mg} \mathrm{l}^{-1}\right), C_{e}$ is the final $\mathrm{Hg}$ concentration in the solution $\left(\mathrm{mg} \mathrm{l} \mathrm{l}^{-1}\right.$ ), and $m$ is the yeast cell dry weight ( $\mathrm{gdw}$ ). The time at which the $\mathrm{Hg}$-adsorption equilibrium was attained by the resting yeast cells was determined.

\section{Desorption of $\mathrm{Hg}$ from loaded yeast cells}

The desorption assay was performed as previously reported (Goyal et al. 2003): aqueous $0.1 \mathrm{~mol} \mathrm{l}^{-1} \mathrm{NaOH}, 6.0 \mathrm{mmol} \mathrm{l}^{-1}$ $\mathrm{KCl}, 5.0 \mathrm{mmol}^{-1} \mathrm{CaCl}_{2}$, and $5.0 \mathrm{mmol}^{-1}$ EDTA were used as the desorption solutions. A cell mass previously loaded with $\mathrm{Hg}$ through biosorption was harvested $(9000 \times \mathrm{g}, 10 \mathrm{~min})$, washed with physiological phosphate buffer, and treated with the desorption solution $(50.0 \mathrm{ml})$ at $30{ }^{\circ} \mathrm{C}$ with shaking $(100$ rpm). The desorption with $\mathrm{NaOH}$ was allowed to continue for $20 \mathrm{~min}$, whereas the other solutions were incubated for $8 \mathrm{~h}$ due to the disparity between the ionic strength of $\mathrm{NaOH}$ and that of the other solutions. The supernatant was separated $(9000 \times g$, $10 \mathrm{~min}$ ), and its $\mathrm{Hg}$ content was analyzed. Sterile $\mathrm{Hg}-$ supplemented broth and broth without $\mathrm{Hg}$ inoculated with resting cells were used as the controls, and these were subjected to the same experimental conditions.
Bioaccumulation of mercury by actively growing yeast cells

The yeast inoculum $(1 \mathrm{ml})$, which was prepared as described above, was inoculated into $100 \mathrm{ml}$ of YM broth supplemented with $\mathrm{Hg}\left(0,3.0,6.0,12.0,24.0\right.$, and $\left.48.0 \mathrm{mg} \mathrm{l}^{-1}\right)$ in $500-\mathrm{ml}$ Erlenmeyer flasks, and the culture was incubated at $30^{\circ} \mathrm{C}$ and $50 \mathrm{rpm}$ for $48 \mathrm{~h}$. The growth of the yeast strains was monitored every $6 \mathrm{~h}$ based on the turbidity, which was determined by measuring the $\mathrm{OD}_{(600 \mathrm{~nm})}$ using a UV-visible spectrophotometer. The blank was uninoculated YM broth supplemented with the appropriate $\mathrm{Hg}$ concentration. The growing cell of each sample was harvested $(10,000 \times g, 10 \mathrm{~min})$, and the supernatant was separated into a new tube. The pellet was washed three times with saline solution $(0.8 \% \mathrm{NaCl})$, ovendried $\left(105^{\circ} \mathrm{C}\right)$ overnight, and weighed. The culture, supernatant, and pellets were analyzed to determine their $\mathrm{Hg}$ content as explained below. The controls were the same as those described above.

\section{Analyses of total mercury}

The total mercury amounts in $100 \mu$ of the culture medium and supernatant (obtained from the $\mathrm{Hg}$ removal experiments) were determined directly without any pre-treatment using a fully automated thermal vaporization mercury analysis system, i.e., Mercury/MA-3000 (Nippon Instrument Corp., Osaka, Japan). The atomic absorbance of the atomized $\mathrm{Hg}$ was measured at a wavelength of $253.7 \mathrm{~nm}$. The instrument was calibrated with standard $\mathrm{Hg}$ solution (BDH, Leicestershire, England) at concentrations ranging from 0.1 to $100.0 \mathrm{mg}^{-1}$. The amount of volatilized $\mathrm{Hg}$ was determined by subtracting residual amount of $\mathrm{Hg}$ from initial amount in $100 \mu \mathrm{l}$ of the culture medium.

$\mathrm{Hg}^{0}$ volatilization assay during yeast growth

The volatilization of $\mathrm{Hg}^{2+}$ to $\mathrm{Hg}^{0}$ during growth of yeast cells was confirmed qualitatively as previously described (Nakamura and Nakahara 1988) and quantitatively in terms of the depletion of $\mathrm{Hg}$. For the qualitative assay, the yeast strains were cultivated in YM broth or YM agar supplemented with $40 \mu \mathrm{mol} \mathrm{l}{ }^{-1} \mathrm{HgCl}_{2}$. After $48 \mathrm{~h}$ of incubation $\left(30^{\circ} \mathrm{C}\right)$, the colonies on the YM agar plates were harvested and suspended in $100 \mu$ of phosphate buffer $\left(7 \mathrm{mmol} \mathrm{l}^{-1}, \mathrm{pH} 7\right)$ containing $0.5 \mathrm{mmol} \mathrm{l}^{-1}$ EDTA, $0.2 \mathrm{mmol}^{-1}$ magnesium acetate, and $5 \mathrm{mmol} \mathrm{l}^{-1}$ sodium thioglycolate with $\mathrm{HgCl}_{2}\left(100 \mu \mathrm{mol} \mathrm{l}{ }^{-1}\right)$ or without $\mathrm{HgCl}_{2}$ as the control. For the detection of $\mathrm{Hg}$ volatilization using the YM broth culture, $100 \mu \mathrm{l}$ of the culture was mixed with $100 \mu \mathrm{mol}{ }^{-1} \mathrm{HgCl}_{2}$ (final concentration). The suspensions were diluted with buffer, described above, to obtain an $\mathrm{OD}_{(600 \mathrm{~nm})}$ of 0.2 . The suspensions were transferred to a microplate, covered with a medical X-ray film (Fujifilm RX-U; Fujifilm Corp., Tokyo, Japan), and cultivated 
for $8 \mathrm{~h}$ at $30^{\circ} \mathrm{C}$ in the dark. The foggy areas on the film, which are due to the reduction of the $\mathrm{Ag}^{+}$emulsion of the film by gaseous $\mathrm{Hg}^{0}$, were thus interpreted as $\mathrm{Hg}$ volatilization. Sterile buffer with and without $\mathrm{HgCl}_{2}$ was used as the negative control, whereas Bacillus megaterium MB1, which harbors the merA gene in its chromosome and expresses $\mathrm{Hg}^{2+}$ reductase (Huang et al. 1999), was used as the positive control.

\section{Statistical analyses}

All of the statistical tests were performed using the Prism 5 software program (GraphPad software, San Diego, CA, USA).

Definition of resting cells and growing cells of the yeasts

"Resting cells" are yeast cells that are harvested after approximately $10^{6}$ cells $\mathrm{ml}^{-1}$ as $\mathrm{OD}_{600} 0.1$ growth was obtained, harvested, and washed twice; the cells are metabolically active but they are not multiplying. While "growing cells" are cells in nutrient medium that are increasing in population and consequently increasing in biomass as time of incubation changes.

\section{Results}

Sampling, isolation, $\mathrm{Hg}$ resistance, and identification of yeast strains

The two Hg-resistant yeast strains were isolated from lagoon sediment that had total mercury concentration of $95 \mathrm{mg} \mathrm{kgdw}^{-1}$. The yeast strains grew well in YM medium containing $8 \% \mathrm{NaCl}$ and showed resistance, as MIC, to $44.0 \mathrm{mg} \mathrm{l}^{-1} \mathrm{Hg}\left(220 \mu \mathrm{M} \mathrm{HgCl}_{2}\right)$. Based on their 18S rDNA sequences, the yeast strains were identified as species of Yarrowia because they exhibited some relatedness, as determined by their occupation of the same clade in the phylogenetic tree depicted in Fig. S1.
Hg (II) removal

\section{Adsorption equilibrium of $\mathrm{Hg}$ (II) by resting yeast cells}

The resting cells of the two yeast strains adsorbed a major fraction of $\mathrm{Hg}^{2+}$ within the first 15-min exposure followed by an almost negligible increase after $60 \mathrm{~min}$. The adsorption equilibria were attained $80 \mathrm{~min}$ (strain Idd1) and $100 \mathrm{~min}$ (strain Idd2) after inoculation. $\mathrm{Hg}$ adsorbed by resting yeast cells at equilibrium $\left(\mathrm{Q}_{\mathrm{e}} \mathrm{mg} \mathrm{gdw}^{-1}\right)$ as a function of the concentration of $\mathrm{Hg}$ in the solution at equilibrium $\left(C_{e}\right)$ $\left(\mathrm{m} \mathrm{l}^{-1}\right)$ was expressed by the Langmuir model equation $\left(Q_{e}=\frac{Q_{\max } C_{e}}{\frac{1}{b}+C_{e}}\right)$ in a linear form as $\frac{1}{Q_{e}}=\frac{1}{Q_{\max } b} \times \frac{1}{C_{e}}+\frac{1}{Q_{\max }}$ (see Fig. 1a); where $Q_{\max }$ (maximum Hg uptake, $\mathrm{mg} \mathrm{gdw}^{-1}$ ) and $b$ (affinity between $\mathrm{Hg}^{2+}$ and the resting yeast cells) are the Langmuir constants. The Langmuir adsorption constants evaluated from the isotherms, as well as their correlation coefficients $\left(R^{2}\right)(\geq 0.9)$ show that the Langmuir model provided a fit for the experimental data (Table 1). The Hg adsorption data indicates that strain Idd 2 is characterized by a higher maximum $\mathrm{Hg}^{2+}\left(59 \mathrm{mg} \mathrm{gdw}^{-1}\right)$ than strain Idd1 $\left(32 \mathrm{mg} \mathrm{gdw}^{-1}\right)$. The Langmuir affinity (saturation) constant $(1 / b)$ was marginally higher in strain Idd $1\left(17 \mathrm{mg}^{-1}\right)$ than Idd $2\left(6.5 \mathrm{mg}^{-1}\right)$. Mercury removal percentage of the resting cells is represented in Fig. 2, where more than $99 \%$ of available $\mathrm{Hg}^{2+}$ was removed at low metal concentration $\left(4 \mathrm{mg}^{-1}\right)$. At high metal concentration $\left(64 \mathrm{mg} \mathrm{l}^{-1}\right)$, however, resting cells of Idd1 removed $\mathrm{Hg}^{2+}$ more efficiently $(84 \pm 2 \%)$ than Idd2 (78 \pm $4 \%)$.

The pseudo-first-order rate equation, $\operatorname{In}\left(Q_{e}-Q_{t}\right)=\operatorname{In} Q_{e}-$ $k_{1} t$, and the pseudo-second-order rate equation, $\frac{t}{Q_{t}}=\frac{t}{Q_{e}}+$ $\frac{1}{k_{2} Q^{2}}$, were represented in their linear forms. In these equations, $Q_{t}$ is the amount of $\mathrm{Hg}^{2+}$ adsorbed $\left(\mathrm{mg} \mathrm{gdw}^{-1}\right)$ at any given time $t(\mathrm{~min}), Q_{e}$ is the amount of $\mathrm{Hg}^{2+}$ adsorbed $\left(\mathrm{mg} \mathrm{gdw}{ }^{-1}\right)$ at equilibrium, and $k_{1}$ and $k_{2}$ are the rate constants of the pseudo-first-order reaction and the pseudo-secondorder reaction for biosorption, respectively. For the analysis of the applicability of the pseudo-first-order kinetic model, a
Fig. 1 a Adsorption equilibrium by Langmuir equation and $\mathbf{b}$ adsorption kinetics by pseudosecond-order equation of $\mathrm{Hg}$ (II) on resting cells of yeast strains Idd1 (filled cycle) and Idd2 (filled square). The error bars represent the standard error of the mean from triplicate experiments
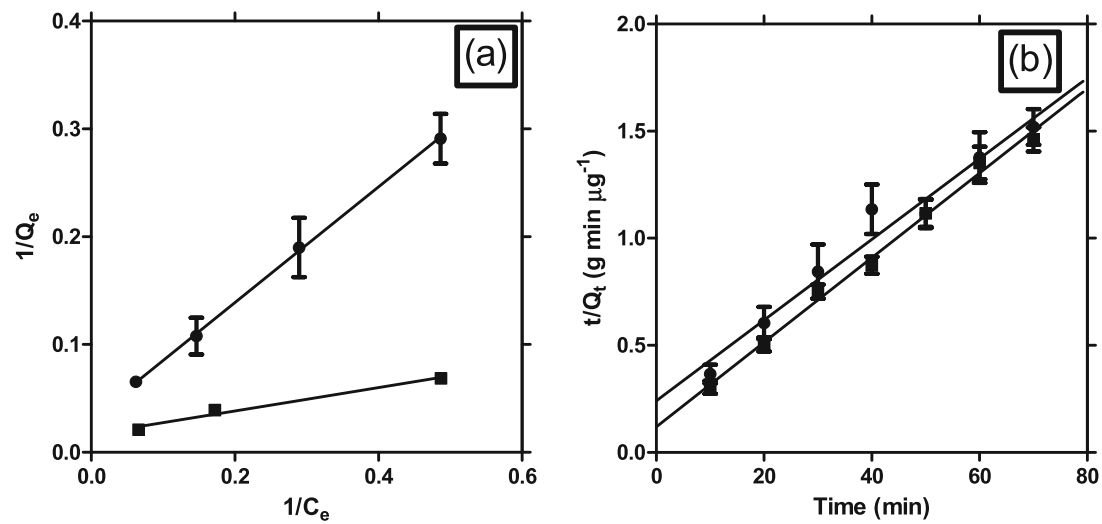
Table $1 \mathrm{Hg}^{2+}$ biosorption kinetics obtained from Langmuir isotherm and pseudo-secondorder rate equation for resting cells of yeast strains

\begin{tabular}{llll}
\hline Kinetic models & Parameters & \multicolumn{2}{l}{ Yeast strains } \\
\cline { 3 - 4 } & & Yarrowia $($ Idd1) & Yarrowia (Idd2) \\
\hline Langmuir equation & $Q_{\max }\left(\mathrm{mg} \mathrm{gdw}^{-1}\right)$ & 32.0 & 59.0 \\
& $1 / b\left(\mathrm{mg} \mathrm{l}^{-1}\right)$ & 17.0 & 6.5 \\
& $R^{2}$ & 0.91 & 0.98 \\
Pseudo second order & $P$ & $<0.0001$ & $<0.0001$ \\
& $k_{2}\left(\mathrm{mg}^{-1} \mathrm{gdw} \mathrm{min}^{-1}\right)$ & 1.5 & 3.3 \\
& $Q_{e}\left(\mathrm{mg} \mathrm{gdw}^{-1}\right)$ & 53.0 & 51.0 \\
& $R^{2}$ & 0.86 & 0.96 \\
& $P$ & $<0.0001$ & $<0.0001$ \\
\hline
\end{tabular}

plot of In $\left(Q_{e}-Q_{t}\right)$ as a function of $t$ did not yield straight lines (Fig. S1). However, a plot of $t / Q_{t}$ as a function of $t$ resulted in straight lines, thereby indicating the applicability of the pseudo-second-order kinetic model (Fig. 1b). The calculated values of $Q_{e}$ and $k_{2}$ are shown in Table 1 . The adsorption of $\mathrm{Hg}$ by the yeasts follows pseudo-second-order kinetics, as inferred by the high values of $R^{2}$.

\section{Desorption of $\mathrm{Hg}$ from resting yeast cells}

The desorption of $\mathrm{Hg}$ from $\mathrm{Hg}$-adsorbed resting yeast cells is shown for strain Idd1 and strain Idd2 (Table 2). Solutions of $\mathrm{CaCl}_{2}(5.0 \mathrm{mM})$ and EDTA $(5.0 \mathrm{mM})$ desorbed 68 and $48 \%$ of the loaded $\mathrm{Hg}$ (II), respectively, from the resting yeast cells of strain Idd2. Hg adhered more strongly to strain Idd1, as indicated by the poorer performance of the desorbing agents (EDTA desorbs $29 \%$ of the adsorbed $\mathrm{Hg}$ from the resting cell mass). In addition, the $\mathrm{NaOH}(0.1 \mathrm{M})$ solution dislodged a negligible portion $(0.02 \%$ from strain Idd 1 and $0.03 \%$ from strain Idd2).

$\mathrm{Hg}$ volatilization and $\mathrm{Hg}$ bioaccumulation by actively growing yeast cells

$\mathrm{Hg}^{2+}$ removal was recorded for each growing strain under the ambient $\mathrm{pH}(5.0-6.5)$ and temperature $\left(30 \pm 2{ }^{\circ} \mathrm{C}\right)$, conditions prevalent in Lagos Lagoon. The yeast strains grew without a lag phase in medium supplemented with $8.0 \mathrm{mg} \mathrm{l}^{-1} \mathrm{Hg}^{2+}$ (and lower $\mathrm{Hg}^{2+}$ concentrations), and the characteristic growth pattern observed was similar to that obtained in medium without $\mathrm{Hg}^{2+}$ supplementation. However, at higher $\mathrm{Hg}$ concentrations $\left(\geq 16.0 \mathrm{mg} \mathrm{l}^{-1}\right)$, a lag phase $(\geq 12 \mathrm{~h})$ preceded the spontaneous growth of both strains. Adsorption and volatilization of $\mathrm{Hg}$ were observed during the lag phase. $\mathrm{Hg}$ bioaccumulation began during the exponential growth phase and increased during the stationary phase. The mass balance of $\mathrm{Hg}^{2+}$ in the batch culture system was presented in Table 3. Volatilization due to the release of $\mathrm{Hg}^{0}$ from the growing yeast cultures was observed based on the development of foggy areas on the X-ray film (Fig. S3).

\section{Discussion}

Reckless waste disposal of industrial and artisanal activities are the major anthropogenic sources through which $\mathrm{Hg}$ contaminates the environment throughout the world (AMAP/UNEP 2013). The total Hg concentration in the sediment is higher than those reported in other climes (Tomiyasu et al. 2008) and alarmingly above the permissive level in the environment. Severe hazards to public health and estuarine ecosystems due to $\mathrm{Hg}$ toxicity are imminent because there is no known mitigation plan to salvage the continual pollution of the water bodies with Hg-laden effluents. The isolation of highly Hg-resistant yeast strains from the sediment in a

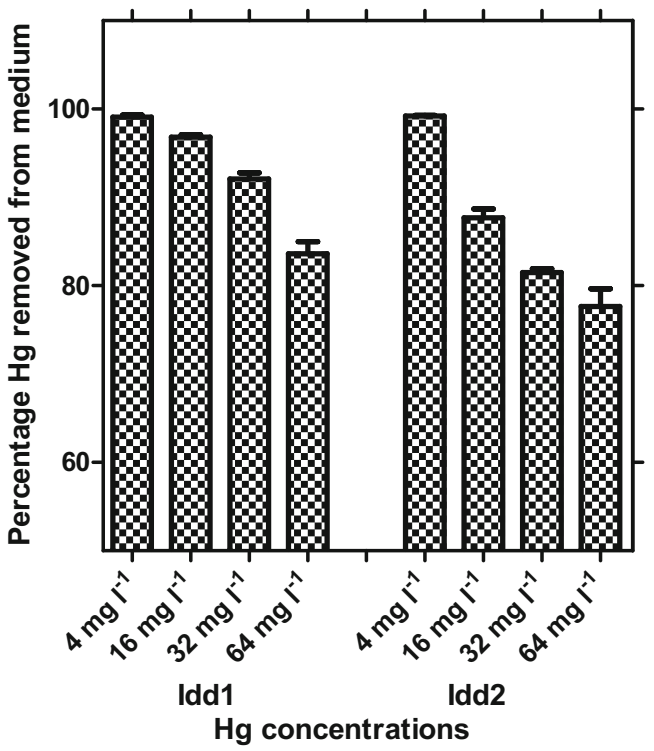

Fig. 2 Efficiencies of $\mathrm{Hg}$ removal by resting cells of yeast strains Idd1 and Idd2 in medium supplemented with various concentrations of $\mathrm{HgCl}_{2}$. The error bars represent the standard error of the mean from triplicate experiments 
Table 2 Desorption of $\mathrm{Hg}^{2+}$ from yeast strains Idd1 and Idd2 using selected desorbents

\begin{tabular}{lll}
\hline & \multicolumn{2}{l}{ Mercury desorbed from yeast cells $(\%)$} \\
\hline Desorption solution & Idd1 & Idd2 \\
EDTA & $29.0( \pm 1.4)$ & $24.0( \pm 6.0)$ \\
$\mathrm{KCl}$ & $3.2( \pm 0.53)$ & $11.0( \pm 1.0)$ \\
$\mathrm{CaCl}_{2}$ & $7.0( \pm 1.6)$ & $33.0( \pm 18.0)$ \\
$\mathrm{NaOH}$ & $2.3( \pm 0.2)$ & $1.6( \pm 0.085)$ \\
\hline
\end{tabular}

Desorption conditions were EDTA $\left(5 \mathrm{mmol} \mathrm{l}^{-1}, 8 \mathrm{~h}\right), \mathrm{KCl}\left(5 \mathrm{mmol} \mathrm{l}^{-1}\right.$, $8 \mathrm{~h}), \mathrm{CaCl}_{2}\left(5 \mathrm{mmoll}^{-1}, 8 \mathrm{~h}\right)$, and $\mathrm{NaOH}\left(0.1 \mathrm{moll}^{-1}, 20 \mathrm{~min}\right)$. The $\mathrm{Hg}^{2+}$ quantities adsorbed by Idd1 and Idd2 were $55.0( \pm 2.4) \mathrm{mg} \mathrm{gdw}^{-1}$, and $49.0( \pm 3.2) \mathrm{mg} \mathrm{gdw}^{-1}$, respectively. Desorption reactions were conducted with shaking $(50 \times \mathrm{g})$ at a temperature of $30{ }^{\circ} \mathrm{C}$. The values indicate the mean $( \pm \mathrm{SD})$ from triplicate experiments

mercury contaminated lagoon is an indication of the contamination of the estuarine water-course with mercuric ions. As a bio-indicator of mercuric pollution, the autochthonous yeast strains in the lagoon must have molecular alterations to evolve the high $\mathrm{Hg}$ resistance.

The equilibrium distribution of mercuric ions between the aqueous and solid phases is represented by the biosorption rate and the maximum biosorption capacity, which is commonly described by the Langmuir isotherm model (Febrianto et al. 2009). The resting cells of both strains adsorb $\mathrm{Hg}^{2+}$ from solution at an almost equal rate. The high $Q_{\max }$ observed in $\mathrm{Hg}$ adsorption indicates that resting cells of strain Idd2 has a higher number of sites available for $\mathrm{Hg}$ binding and belongs to a single-type phenomenon with no interactions between the adsorbed $\mathrm{Hg}$. The lower Langmuir saturation constant of strain Idd 2 than that of strain Idd 1 indicates the adsorption affinity of the resting yeast strain Idd2 for mercuric ions is higher than strain Idd1. However, certain inconsistencies in the saturation capacities $\left(Q_{\max }\right)$ of Langmuir equation, and $\mathrm{Hg}^{2+}$ uptake at equilibrium $\left(Q_{e}\right)$ were observed. The rather higher $Q_{e}\left(53.0 \mathrm{mg} \mathrm{gdw}^{-1}\right)$ than predicted $Q_{\max }$ $\left(32.0 \mathrm{mg} \mathrm{gdw}^{-1}\right)$ recorded for strain Idd1 may be associated with the surface functional groups, and effects of several factors including number of binding sites, chemical state of the sites, and binding strength of the sites, as previously discussed by Febrianto et al. (2009).
The kinetics of $\mathrm{Hg}^{2+}$ biosorption on resting yeast cells of Yarrowia spp. was determined using the pseudo-second-order model based on solid-phase adsorption (Febrianto et al. 2009) (Fig. $1 \mathrm{~b}$ and Table 1). The results suggest that chemisorption may be the rate-limiting step that controls the uptake of $\mathrm{Hg}^{2+}$ from aquatic systems. The rate-control may vary during the course of $\mathrm{Hg}^{2+}$ biosorption (Febrianto et al. 2009). An external surface mass transfer or a film diffusion process may control the early stages of the $\mathrm{Hg}^{2+}$ biosorption process onto resting cells of the yeast strains. This stage may be followed by a chemical reaction or constant rate stage and then by a diffusion stage in which the biosorption process slows down considerably (Djeribi and Hamdaoui 2008). It is noteworthy that good fitting model does not necessarily illustrate the nature of real adsorption between the resting cells and $\mathrm{Hg}^{2+}$ due to dynamic characteristics of all living cells unlike dead cells.

Desorption upon treatment with calcium and potassium showed a lower desorption performance of strain Idd1 than that of strain Idd2. This negates the potential reusability of strain Idd1 in the treatment of mercury-laden wastewater. From these data, the resting cells of strain Idd 2 would be a better option in the treatment of wastewater laden with mercuric ions, since the adsorbed mercuric ions could be readily recovered from the resting cells. The results of $\mathrm{Hg}$ desorption from the resting cell masses may indicate that salt cations, particularly $\mathrm{Ca}^{2+}$, in estuarine water can readily desorb $\mathrm{Hg}$ from the resting cells of strain Idd2 (Table 2), and thereby spread the toxic metal to other parts of the ecosystem. However, strain Idd 2 would be of great value for the treatment of industrial wastewater due to its reusability and the potential ability to recover $\mathrm{Hg}$ from the resting yeast cells. The poor desorption potential of strain Iddl coupled with its higher $Q_{\max }$ demonstrates that the organism may act as an $\mathrm{Hg}$ (II) sink in the limnetic zone. However, strain Idd1 would not have predominance over strain Idd2 in recovery of $\mathrm{Hg}$ and reusability of the yeast cells for $\mathrm{Hg}$ removal in a bioreactor system.

$\mathrm{Hg}^{2+}$ reduction to $\mathrm{Hg}^{0}$ and $\mathrm{Hg}^{0}$ volatilization (Table 3 and Fig. S3) were likely triggered by sulfhydryl compounds present in the biomolecules produced by the growing yeast strains in response to $\mathrm{Hg}$ toxicity. Larger amount of mercury was reduced and volatilized by the growing strain Idd1 than the growing strain Idd2. Recently, Rao et al. (2013) reported the role played by strong reducing agents in facilitating efficient metal removal by Yarrowia lipolytica. It has been reported that

Table 3 Mercury removal by yeast strains Idd1 and Idd2 during growth in medium supplemented with $32 \mathrm{mg} \mathrm{Hg}^{2+}$ per liter

\begin{tabular}{llll}
\hline Yeast strains & $\begin{array}{l}\text { Mercury remaining } \\
\text { in medium }^{\mathrm{a}}(\%)\end{array}$ & $\begin{array}{l}\text { Mercury accumulated onto } \\
\text { growing yeast cells }\end{array}$ & $\begin{array}{l}\text { Mercury volatilized by } \\
\text { growing yeast cells }\end{array}$ \\
\hline Idd1 $(\%)$
\end{tabular}

${ }^{\mathrm{a}}$ Total mercury is expressed as percentages of the initial $\mathrm{Hg}$ content in the medium upon inoculation. Values represent the mean ( \pm standard deviation) from triplicate experiments 
mercury is transported across the vacuolar membrane to become localized in the vacuoles of Saccharomyces cerevisiae (Diffels et al. 2006). Certain proteins (Strouhal et al. 2003) and/or interactions with sulfhydryl-containing residues have been hypothesized to be responsible for $\mathrm{Hg}$ bioaccumulation in microorganisms (Hansen et al. 2006; Park and Park 2007; Pulido and Parrish 2003). Concrete evidence of the actual organic biomolecules involved in $\mathrm{Hg}$ reduction and transportation by Yarrowia spp. remains to be obtained.

Based on the results described above, characteristics of mercury removal by the resting and growing cells of yeast strains Yarrowia sp. Idd 1 and Idd 2 isolated in this study were observed. The resting cells of yeast strain Idd 2 would be applicable to $\mathrm{Hg}$ removal and recovery from mercury-laden water as a more appropriate and reusable bio-adsorbent. In contrast, the growing cells of yeast strain Idd1 would be applicable as an appropriate $\mathrm{Hg}^{2+}$ bio-reduction and volatilization agent. Therefore, the most appropriate $\mathrm{Hg}$ removal method should be selected according to the removal characteristics of resting cells and growing cells of the yeast strains. However, further studies are needed to understand detailed physiological Hg removal mechanisms of the resting and growing cells of yeast strains, by analyzing biomolecules involved in the $\mathrm{Hg}$ reduction and adsorption.

Acknowledgments We thank Dr. Mei-Fang Chien and Toshiki Kurosawa for their useful discussion and assistance during the experiment. GOO and GE appreciate the Japan Society for the Promotion of Science (JSPS) for the awarding of Postdoctoral Research Fellowship FY20122013. This work was funded by Grants-in-Aid (No. 24-02373) for Scientific Research from the JSPS

Open Access This article is distributed under the terms of the Creative Commons Attribution License which permits any use, distribution, and reproduction in any medium, provided the original author(s) and the source are credited.

\section{References}

AMAP/UNEP (2013) Global releases of mercury to aquatic environments. In: Technical background report for global mercury assessment. Pp 263

ATSDR (2008) Public health statement: toxic substances and health. Agency for toxic substances and disease registry, Atlanta, GA: Division of toxicology and environmental medicine September bulletin

Bankar AV, Kumar AR, Zinjarde SS (2009) Removal of chromium (VI) ions from aqueous solution by adsorption onto two marine isolates of Yarrowia lipolytica. J Hazard Mater 170:487-494

Diffels JF, Seret ML, Goffeau A, Baret PV (2006) Heavy metal transporters in Hemiascomycete yeasts. Biochimie 88:1639-1649

Djeribi R, Hamdaoui O (2008) Sorption of copper (II) from aqueous solutions by cedar sawdust and crushed brick. Desalination 225:95-112

Febrianto J, Kosasih AN, Sunarso J, Ju Y-H, Indraswati N, Ismadji S (2009) Equilibrium and kinetic studies in adsorption of heavy metals using biosorbent: a summary of recent studies. J Hazard Mater 162: 616-645
Francois F, Lombard C, Guigner J-M, Soreau P, Brian-Jaisson F, Martino G, Vandervennet M, Garcia D, Molinier A-L, Pignol D, Peduzzi J, Zirah S, Rebuffat S (2012) Isolation and characterization of environmental bacteria capable of extracellular biosorption of mercury. Appl Environ Microbiol 78:1097-1106

Goyal N, Jain SC, Banerjee UC (2003) Comparative studies on the adsorption of heavy metals. Adv Environ Res 7:311-319

Guzzi G, La Porta CA (2008) Molecular mechanisms triggered by mercury. Toxicology $244: 1-12$

Hansen JM, Zhang H, Jones DP (2006) Differential oxidation of thioredoxin-1, thioredoxin-2, and glutathione by metal ions. Free Radic Biol Med 40:138-145

Huang CC, Narita M, Yamagata T, Itoh Y, Endo G (1999) Structure analysis of a class II transposon encoding the mercury resistance of the Gram positive bacterium, Bacillus megaterium MB1, a strain isolated from Minamata Bay, Japan. Gene 234:361-369

Hussein H, Ibrahim SF, Kandeel K, Moawad H (2004) Biosorption of heavy metals from waste water using Pseudomonas sp. Electron J Biotechnol 7:38-46

Kim E-H, Mason RP, Porter ET, Soulen HL (2004) The effect of resuspension on the fate of total mercury and methyl mercury in a shallow estuarine ecosystem: a mesocosm study. Mar Chem 86:121-137

Nakamura K, Nakahara H (1988) Simplified X-ray film method for detection of bacterial volatilization of mercury chloride by Escherichia coli. Appl Environ Microbiol 54:2871-2873

Nimick DA, Caldwell RR, Skaar DR, Selch TM (2013) Fate of geothermal mercury from Yellowstone National Park in the Madison and Missouri Rivers, USA. Sci Total Environ 443:40-54

Park EJ, Park K (2007) Induction of reactive oxygen species and apoptosis in BEAS-2B cells by mercuric chloride. Toxicol in Vitro 21:789-794

Pulido MD, Parrish AR (2003) Metal-induced apoptosis: mechanisms. Mutat Res/FMMM 533:227-241

Puranik PR, Paknikar KM (1999) Biosorption of lead, cadmium, and zinc by Citrobacter strain MCM B-181: characterisation studies. Biotechnol Prog 15:228-237

Rao A, Bankar A, Kumar AR, Gosavi S, Zinjarde S (2013) Removal of hexavalent chromium ions by Yarrowia lipolytica cells modified with phyto-inspired $\mathrm{Fe}^{0} / \mathrm{Fe}_{3} \mathrm{O}_{4}$ nanoparticles. J Contam Hydrol 146:63-73

Strouhal M, Kizek R, Vacek J, Trnkova L, Nemec M (2003) Electrochemical study of heavy metals and metallothionein in yeast Yarrowia lipolytical. Biogeosciences 60:29-36

Tchounwon PB, Ayensu WK, Ninashvili N, Sutton (2003) Environmental exposure to mercury and its toxicopathologic implications for public health. Environ Toxicol 18:149-175

Tomiyasu T, Matsuyama A, Eguchi T, Fuchigami Y, Oki K, Horvat M, Rajar R, Akagi H (2006) Spatial variations of mercury in sediment of Minamata Bay, Japan. Sci Total Environ 368:283-290

Tomiyasu T, Matsuyama A, Eguchi T, Marumoto K, Oki K, Akagi H (2008) Speciation of mercury in water at the bottom of Minamata Bay, Japan. Mar Chem 112:102-106

Velasquez L, Dussan J (2009) Biosorption and bioaccumulation of heavy metals on dead and living biomass of Bacillus sphaericus. J Hazard Mater 167:713-716

Voleski B (1994) Advances in biosorption of metals: selection of biomass types. FEMS Microbiol Rev 14:291-302

von Canstein H, Li Y, Timmis KN, Deckwer W-D, Wagner-Döbler I (1999) Removal of mercury from chlor-alkali electrolysis wastewater by a mercury-resistant Pseudomonas putida strain. Appl Environ Microbiol 65:5279-5284

von Canstein H, Kelly S, Le Y, Wagner-Döbler I (2002) Species diversity improves the efficiency of mercury-reducing biofilms under changing environmental conditions. Appl Environ Microbiol 68:2829-2837

Yavuz H, Denizli A, Gungunes H, Safarikova M, Safarik I (2006) Biosorption of mercury on magnetically modified yeast cells. Sep Purif Technol 52:253-260 